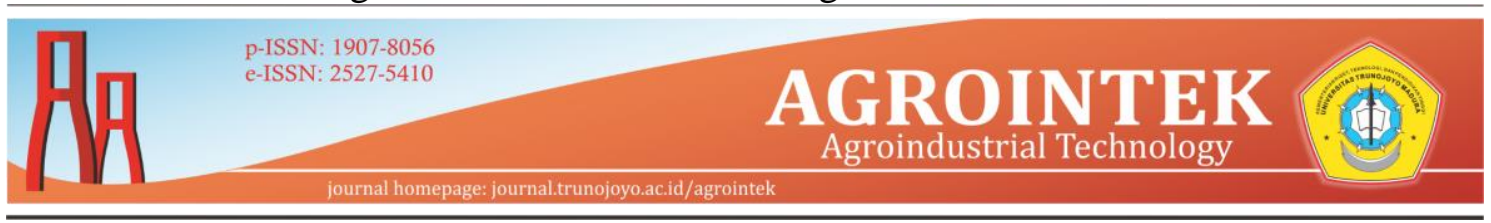

\title{
THE EFFECT OF MILLING METHOD ON PROTEIN PROFILE IN SORGHUM (Sorghum bicolor L.) KD-4 VARIETY
}

\author{
Kendri Wahyuningsih ${ }^{1 \dagger}$, Lusy Rismayani ${ }^{2}$, Endang Yuli Purwani ${ }^{1}$, Irma Herawati Suparto ${ }^{2}$ \\ ${ }^{1}$ Indonesian Center for Agricultural Postharvest Research and Development, Bogor, Indonesia \\ ${ }^{2}$ Department of Chemistry, Institut Pertanian Bogor, Bogor, Indonesia
}

Article history

Diterima: 8 Maret 2019

Diperbaiki:16 Juni 2019

Disetujui: 17 Juli 2019

$\underline{\text { Keyword }}$

milling,

protein fractions,

sorghum bran,

sorghum flour

\begin{abstract}
Milling is of important process to improve nutritional and palatability of sorghum seeds for human consumption. This study investigated the effect of milling process on protein fraction of sorghum flour and the bran. The result showed that dry milled sorghum flour contained higher protein than those of wet milled sorghum flour, and the highest protein content was found on sorghum bran. Dry-milled sorghum flour has protein fraction in albumin, globulin, kafirin and glutelin higher than those of wet-milled sorghum flour. Wet-millled sorghum flour contained high protein fraction in cross link kafirin and cross link glutelin. Different of protein fractions noticed among the samples suggested that the samples contained different in amount of extractable protein and this was due to the differences in total protein.
\end{abstract}

(C) All right reserved

\footnotetext{
$\dagger$ Penulis korespondensi Email: eyplab@gmail.com DOI: http://dx.doi.org/10.21107/agrointek.v13i2.5034
} 


\section{INTRODUCTION}

Sorghum (Sorghum bicolor L.) is one of the important cereal crops in Indonesia. Sorghum can grow in semi-arid (dry) regions (Duodu et al., 2003) and contents a number of nutrition, they are: $70 \%$ to $80 \%$ carbohydrate, $11 \%$ to $13 \%$ protein, $2 \%$ to $5 \%$ fat, $1 \%$ to $3 \%$ fiber, and $1 \%$ to $2 \%$ ash. Sorghum seeds contents protein of around $6 \%$ to $18 \%$ with an average of 11\% (Mesa-Stonestreet et al., 2010).

Sorghum is one of the cereals that have the potential to be processed into flour. The texture and physicochemical character of sorghum flour are close to wheat flour (Suarni and Patong, 2002). The advantage of sorghum flour is that it has long shelf life, easy to be stored and distributed, flexible, easily to be mixed and fortified to improve its nutritional quality (Widowati and Damardjati, 2001; Suarni and Patong, 2002). Milling process of sorghum before the process of seed shedding of sorghum seeds is done to reduce the layer of endosperm in sorghum seeds and produce side product in the form of bran. Therefore, this process can improve the taste of sorghum because of it can decrease tannin contented in sorghum seeds. However, the milling process of sorghum, either through wet or dry milling methods, can affect the chemical composition and physico-chemical characteristics of the sorghum flour produced (Chiang and Yeh, 2002; Yoenyong-buddhagal and Noomhorm, 2002; Suksomboon and Naivikul, 2006). Schons et al. (2012) mentioned that the processing of sorghum seeds into flour through processes of fermentation, soaking, germination, and decortication can reduce the number of anti-nutrient factors in it.

Currently, the use of protein from sorghum flour and bran is still not optimal, even though it can help human to fulfill their protein need from food they consume (Afify et al., 2012). The increase of productivity of sorghum plants unlocks the potential of sorghum flour and its bran to be well developed in Indonesia. According to Afify et al. (2012), sorghum protein can be fractionated into four types based on its solubility, including albumin (water soluble), globulin (soluble in salt), prolamin (soluble in alcohol), and glutelin (soluble in acid or base). Protein solubility is one of the critical functional attributes needed as food ingredient. This is because protein solubility is the first criterion used as a basis for classifying proteins and has a major influence in increasing the nutrient content of the food functional properties, such as water and oil binders, emulsification, gelation, viscosity and foam formation (Ragab et al., 2004). The functional properties of protein depend on how much they are in the food products (Pinciroli et al., 2009). In addition, protein also play an important role in determining the properties of pastes and textures (Baxter et al. (2004)). Plant proteins in food processing are used as functional ingredients to improve stability, texture and quality of nutrients from food products (El Nasri and Tinay, 2007). The types of proteins commonly found in plants, such as rice, wheat, nuts, seeds, etc., are albumin, globulin, prolamin, and glutelin (Pedroche et al., 2005). Therefore, learning the characteristics of each of sorghum protein fractions is crucial to obtain proteins that have nutritional value and added value to the food industry. The objective of this study aimed to determine the effect of the dry and wet milling methods on the protein fractions and characteristics of the milled sorghum flour and bran. 


\section{METHODS}

\section{Materials}

Sorghum seeds of a local variety (KD-4) were purchased from a farmer at Lamongan-East Java. The seeds were carefully cleaned and freed from the extraneous matters. The other materials were distilled water, $\mathrm{NaCl}$ (Sodium chloride), 2-propanol, borate buffer, 2mercapto ethanol (2-ME), sodium dodecyl sulfate (SDS), bovine serum albumin (BSA), Lowry's reagent $\left(\mathrm{Na}_{2} \mathrm{CO}_{3}\right.$, $\mathrm{CuSO}_{4} .5 \mathrm{H}_{2} \mathrm{O}$, potassium sodium tartaric, $\mathrm{NaOH}$, Folin-Ciocalteu, acrylamide-bis stock solution, buffer tris $(\mathrm{pH} 8.8$ and $\mathrm{pH}$ 6.8), ammonium persulfate (APS), TEMED (Tetrametiletilendiamin), nbutanol, pure protein, RSB (Reducing Sample Buffer), Coomasie Blue R-250, methanol, astetat acid, and TCA (trichloroacetic acid) solution, Standart protein marker ( alpha-lactal bulmin: 15 kD) were purchased from Sigma Chemical Co., trypsinogen from bovine pancreas $(20 \mathrm{kD})$, carbonic anhydrase from bovine erythrocytes $(25 \mathrm{kD})$, albumin fromchicken egg white (37kD), BSA (50-75 kD), and myosin from porcine muscle(150-250 kD) (Susanto, 2010).

\section{Sample preparation}

Sorghum seeds were milled four times by using an abrasive tool to obtain dhal (sorghum rice). Sorghum rice or dhal was ground using a wet and dry methods by an edible pulp grinding machine. In the dry grinding method, the dried sorghum rice or dhal was directly ground dry until sorghum flour is obtained. In wet milling method, the sorghum or dhal rice was first soaked in water for 24 hours, then ground until a sorghum porridge was obtained. The sorghum porridge was then pressed by using a hydraulic press and dried using a cabinet tray dryer at $65^{\circ} \mathrm{C}$ for 8 hours. The grinding process was carried out to obtain a fine 100 mesh flour by using a disk mill tool. The physico-chemical of the sorghum flour analyzed were the color and their chemical contents, i.e. moisture, nitrogen, and protein content.

\section{Protein fractionation}

The protein fractionation of sorghum flour was done by extraction following the method of the extraction used six solvents, namely: distilled water for albumin, $0.5 \mathrm{M}$ of $\mathrm{NaCl}$ for globulin, 60\% 2-Propanol for kafirin, $60 \%$ 2-propanol with $0.6 \%$ 2-ME for cross-linked kafirin, $0.1 \mathrm{M}$ borate buffer $\mathrm{pH} 10.8$ for glutelin, $0.1 \mathrm{M}$ borate buffer $\mathrm{pH} 10.8$ and $0.6 \%$ 2-ME and $0.5 \%$ SDS for cross-linked glutelin. A $20 \mathrm{~mL}$ $\left(25^{\circ} \mathrm{C}\right)$ of distill water was added to $2 \mathrm{~g}$ of the sample and then extracted for 20 minutes by using a shaker. Following the centrifugation at $18,900 \mathrm{~g}$ (for 10 minutes, at $4^{\circ} \mathrm{C}$ ). The supernatant was taken as an albumin and the pellet fraction was extracted for other test.

The pellet from albumin was dissolved with $0.5 \mathrm{M}$ of $\mathrm{NaCl}$ as much as $20 \mathrm{~mL}\left(25^{\circ} \mathrm{C}\right)$ and was extracted for 60 minutes. Next, centrifugation was done at $18,900 \mathrm{~g}$ (for 10 minutes, at $4^{\circ} \mathrm{C}$ ). The supernatant was taken as a globulin fraction and the pellet was extracted for the next test.

The pellet from globulin was dissolved with $60 \%$ 2-propanol as much as $20 \mathrm{~mL}\left(25^{\circ} \mathrm{C}\right)$ and was extracted for 4 hours. The centrifugation was done at $18,900 \mathrm{~g}$ (for 10 minutes, at $4^{\circ} \mathrm{C}$ ). The supernatant was taken as a kafirin fraction and the pellet was extracted for the next test. The pellet from the kafirin was dissolved with $60 \%$ 2-Propanol with $0.6 \%$ $2-\mathrm{ME}$ as much as $20 \mathrm{~mL}\left(25^{\circ} \mathrm{C}\right)$ and was extracted for 4 hours. The centrifugation was done at $18,900 \mathrm{~g}$ (for 10 minutes, at $4^{\circ} \mathrm{C}$ ). The supernatant was taken as a cross-linked fraction of the kafir and the pellet was extracted for the next test. The pellet from the cross-linked kafirin was 
then dissolved with $0.1 \mathrm{M}$ boric buffer $\mathrm{pH}$ 10.8 as much as $20 \mathrm{~mL}\left(25^{\circ} \mathrm{C}\right)$ and was extracted for 4 hours and centrifuged at $18,900 \mathrm{~g}$ (for 10 minutes, at $4^{\circ} \mathrm{C}$ ). The supernatant was taken as a glutelin fraction and pellet extracted for the next test. The glutelin pellet was dissolved with $0.1 \mathrm{M}$ of borat with $\mathrm{pH} 10.80 .6 \% 2-\mathrm{ME}$ buffer and $0.5 \%$ SDS $20 \mathrm{~mL}\left(25^{\circ} \mathrm{C}\right)$ was extracted for 18 hours and was centrifuged at $18,900 \mathrm{~g}$ (for 10 minutes, at $4^{\circ} \mathrm{C}$ ). The supernatant was taken as cross-linked glutelin.

\section{Whiteness measurement}

Whiteness of sorghum flour was measured based on the Hunter method using by chromameter Minolta CR-300 Series the manufacturer's instruction.

\section{Moisture content determination}

The moisture content was determined according to the thermo gravimetric method of AOAC 2006, after drying at $105^{\circ} \mathrm{C}$ for 3 hours. The moisture content value was expressed in $\mathrm{g}$ water/g dry mass.

\section{Crude and soluble protein measurement}

Crude protein contents of sorghum flour and bran were determined according to the Micro-Kjeldahl methods (AOAC 2006). Soluble proteins in each fraction were determined by Lowry et al. (1951). Bovine Serum Albumin was used as standard protein. Soluble protein was expressed as $\mathrm{g} / 100 \mathrm{~g}$ dry weight sample.

\section{Electrophoresis}

The sodium dodecyl sulphate polyacrylamide gel electrophoresis (SDSPAGE) was done following the method of Bollag and Edelstein (1991). Three kinds of solutions, namely solutions $\mathrm{A}, \mathrm{B}$, and C were used. Solution A was made by mixing $29.2 \mathrm{~g}$ acrylamide and $0.8 \mathrm{~g}$ bisacrylamide. Solution B was made by mixing $75 \mathrm{~mL}$ of Tris $\mathrm{HCl} 2 \mathrm{M}(\mathrm{pH}=8.8)$, $4 \mathrm{~mL}$ of SDS $10 \%$, and $21 \mathrm{~mL}$ of aquabides as the buffer in the separating gel. And, solution $\mathrm{C}$ was made by mixing $50 \mathrm{~mL}$ of Tris $\mathrm{HCl} 1 \mathrm{M}$ ( $\mathrm{pH}=6.8), 4 \mathrm{~mL}$ of SDS $10 \%$, and $46 \mathrm{~mL}$ of aquabides as the buffer on the holding gel.

The electrophoretic buffer solutions was made by mixing $3 \mathrm{~g}$ of Tris-base, 14.4 $\mathrm{g}$ glycine, $1 \mathrm{~g} \mathrm{SDS}$, and aquabides to a volume of $1 \mathrm{~L}$ until the $\mathrm{pH}$ solution was adjusted 8.3. The sample buffer was made by mixing $0.5 \mathrm{~mL}$ of betamerkaptoetanol, $0.2 \mathrm{~g}$ SDS, $2.5 \mathrm{~mL}$ glycerol, $0.01 \mathrm{~g}$ bromophenol blue $0.1 \%, 0.60 \mathrm{~mL}$ of Tris$\mathrm{HCl} 1 \mathrm{M}(\mathrm{pH}=6.8)$, and $10 \mathrm{~mL}$ of aquabides. A total of $100 \mu \mathrm{l}$ sample was dissolved with $100 \mu \mathrm{L}$ sample buffer. The loading process was done by using a sample of $15 \mu \mathrm{L}$. A total of $12.5 \%$ separator gel was carried out by mixing $4.2 \mathrm{~mL}$ of solution $\mathrm{A}, 2.5 \mathrm{~mL}$ of solution $\mathrm{B}, 3.3 \mathrm{~mL}$ of aquabides, $0.1 \mathrm{~mL}$ of APS $10 \%$, and $0.01 \mathrm{~mL}$ of TEMED at the end of mixing. The solution was then put into the electrophoresis apparatus.

The $4 \%$ retaining gel was made by mixing $0.335 \mathrm{~mL}$ of solution $\mathrm{A}, 0.6 \mathrm{~mL}$ of solution $\mathrm{C}, 1.5 \mathrm{~mL}$ of aquabides, $0.05 \mathrm{~mL}$ of APS $10 \%$, and $0.01 \mathrm{~mL}$ of TEMED at the end of mixing. The solution was then put into the electrophoresis apparatus above the separating gel. After the gel hardened, the comb was removed and the apparatus box was filled with electrophoresis buffer. The electrophoresis was carried out at a voltage of 100 volts and an electric current of $80 \mathrm{~mA}$ for 2.5 hours. After that, the gel was colored by using Coomasie Blue R-250 staining which included stages of fixation, ethanol washing, sensitization, washing with aquabides, staining, washing with aquabides, developing solution, stopping solution, and washing it by using aquabides. The protein markers used were alpha-lactalbumine (15 kD), trypsinogen from bovine pancreas $(20 \mathrm{kD})$, carbonic anhydrase from bovine erythrocytes (25 
$\mathrm{kD}$ ), albumin fromchicken egg white $(37 \mathrm{kD})$, BSA $(50-75 \mathrm{kD})$, and myosin from porcine muscle $(150-250 \mathrm{kD})$. The coloring used was commasie blue (Susanto, 2010).

\section{Statistic analysis}

The data were analyzed by one-way Analysis of Variance (ANOVA). Duncan`s multiple range test was used to separate means. Significance was accepted at a probability $\mathrm{p}<0.05$.

\section{RESULTS AND DISCUSSION}

\section{Physico-chemical characteristics of sorghum flour and the bran}

The physical and chemical properties of dry and wet milled sorghum flour var KD-4 and their bran were shown in Table 1. The moisture content of the dry and wet milled sorghum flour and bran were $3.27 \%, 6.22 \%$, and $9.59 \%$, respectively.
The water and protein contents of the dry and wet milling sorghum were significantly different, but the degree of whiteness was not significantly different $(\mathrm{P}<0.05)$. The wet milled sorghum flour has higher moisture content than that of the dry milled sorghum. This is due to water absorption during the process of soaking of the sorghum rice or dhal. According to Merdiyanti (2008), during soaking the sorghum seed large amount of water absorbed and the endosperm layer are supported by the data in Table 1 which shows that the water content of sorghum bran $(9.59 \%)$ was the highest, compared to dry milled sorghum flour and wet milled sorghum flour.

The protein content of the dy milled and wet milled sorghum flour, and the bran were $11.82 \%, 7.44 \%$, and $19.85 \%$, respectively.

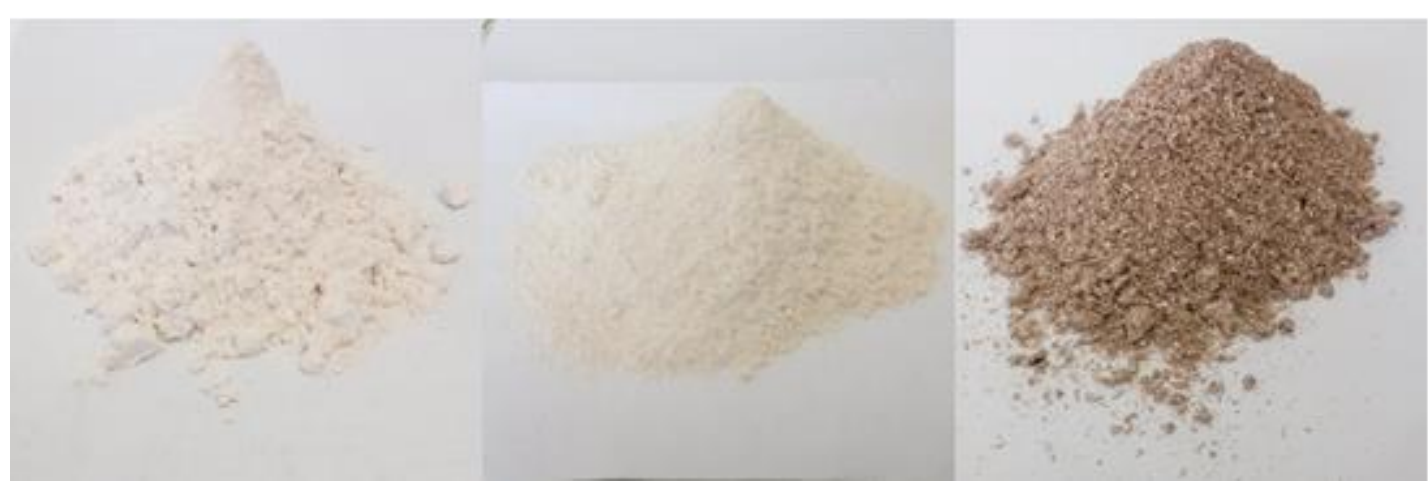

Figure 1 (a) Wet-milled sorghum flour (b) Dry-milled sorghum flour, and (c) Sorghum bran

Table 1 Moisture content, protein content, and whiteness of the dry-milled and wet-milled sorghum flours and the bran sorghum

\begin{tabular}{lccc}
\hline \multicolumn{1}{c}{ Parameters } & $\begin{array}{c}\text { Dry-milled } \\
\text { sorghum flours }\end{array}$ & $\begin{array}{c}\text { Wet-milled } \\
\text { sorghum flours }\end{array}$ & Sorghum bran \\
\hline Whiteness (\%) & $97.66 \pm 0.08^{\mathrm{a}}$ & $97.74 \pm 0.06^{\mathrm{a}}$ & - \\
Moisture (\%) & $3.27 \pm 0.08^{\mathrm{a}}$ & $6.22 \pm 0.01^{\mathrm{b}}$ & $9.59 \pm 0.92^{\mathrm{c}}$ \\
$\begin{array}{l}\text { Protein content* } \\
(\%)\end{array}$ & $11.82 \pm 0.62^{\mathrm{a}}$ & $7.44 \pm 0.62^{\mathrm{b}}$ & $19.85 \pm 0.62^{\mathrm{c}}$ \\
\end{tabular}

Remarks : Values are means \pm SD. Subscript in the same row followed by the same letter are not significantly different at $\mathrm{p}<0.05$. Whiteness, $\mathrm{L}(0)=$ dark, $\mathrm{L}(100)=$ bright. 
The lower protein content in the wet milled sorghum flour $(7.44 \%)$ than that of the dry milled flour $(11.82 \%)$ is probably due to the partial dissolution of protein and loss of the endosperm layer during the immersion process. According to Anglemeir and Montgomery (1976), the decrease in the protein was caused by the release of protein bonds so that some of the protein components are dissolved and the loss of some layers of the endosperm during the sereal immersion process. In addition, it could be due to the separation of a large number of endosperm, aleurons and institutions of the seeds during the time of milling because most the sorghum proteins presented in these parts of the seeds (Suarni and Patong, 2002; Hulse and Pearson, 1980). The high rate of milling of sorghum seeds resulted in the protein content of sorghum bran was at the highest level compared to sorghum flour which was only $19.85 \%$. The research result done by Awadalkareem et al. (2008) showed that the protein contented in sorghum flour was not too high that it is only $14.00 \%$.

The wet-milled sorghum flour had a slightly higher white degree (97.74\%) than that of the dry-milled sorghum flour $(97.66 \%)$ (Figure 1) because the endosperm layer has become soft and released during soaking (Merdiyanti, 2008). Whiteness is one of the important parameters that determines the level of consumer acceptance of sorghum flour. Consumers are generally prefer a very high level of functionality. Milling method, both wet and dry, shows no significant effect on the degree of sorghum flour whiteness $(\mathrm{p}<0.05 \%)$. The degree of whiteness of wet milled sorghum flour is higher because the endosperm layer has become soft and released until it is wasted with soaking water, the immersion process causes the loss of a number of layers of endosperm (Merdiyanti, 2008). Sorghum bran has a brownish red color caused by the content of tannins on sorghum skin.

\section{Protein fraction of sorghum flour and the bran}

The protein fractionation revealed six types of proteins, namely: albumin, globulin, kafirin, cross-linked kafirin, glutelin, and cross-linked glutelin. The results showed that the dry milling method had a higher protein fraction than the wet milling method, except in the kafirin cross-linked fraction where the wet milling protein was higher than the dry milling protein (Figure 2). The bran was also having a higher kafir cross-linked fraction.

From the result on Figure 2, it could be noticed that the dry milled sorghum flour contained $9.13 \%, 6.68 \%, 21.57 \%$, $11.65 \%, 30.67 \%$ and $20.30 \%$, of the total protein for albumins, globulins, glutelins, cross-linked kafirins and cross-linked glutelins, respectively. The wet milled shorgum flour contained $1.99 \%, 2.81 \%$, $21.35 \%, 3.36 \%, 48.16 \%$ and $22.33 \%$ of total protein for albumins, globulins, glutelins, cross-linked kafirins and crosslinked glutelins, respectively. The distribution of protein extracts was extracted with different solvents suggested that, the method of milling different amounts of total extractable protein and this is the difference in total protein. Cross-linked kafirins, represented a considerably greater fraction in sorghum flour obtained were $30.67 \%$ and $48.16 \%$. This shows that the cross-linked kafirin in sorghum flour is higher than the kafirin fraction. The result of this study is closed to Afify et al. (2012) kafirin's crosslinked fraction $(25.55 \% \%$ to $27.00 \%)$ will be more than the kafirin's fraction $(16.37 \%$ to $17.75 \%)$. Since a large percentage of sorghum kafirin storage proteins exist in polymeric forms linked by disulfide bonds in their native state, differences in content of fractions rich in 
insoluble disulfide proteins. Moreover, kafirin and cross-linked kafirin in raw sorghum ranged from 17.30 to $19.90 \%$ and 24.40 to $35.10 \%$, respectively (Duodu et al., 2003). Sorghum has a higher proportion of cross-linked kafirin than maize (Mcdonough et al., 2004).

Table 2 shows a significantly different effect $(\mathrm{p}<0.05)$ on the dry and wet milling method on the protein fraction of sorghum flour. Albumin fraction is a water soluble protein fraction. The albumin fraction in this experiment showed that the wet milled sorghum flour had an average protein concentration of $18.04 \mathrm{mg} / \mathrm{L}$ which was smaller than the average protein concentration of wet milled sorghum flour at $95.77 \mathrm{mg} / \mathrm{L}$. This shows that there is an influence from the dry and wet grinding process.

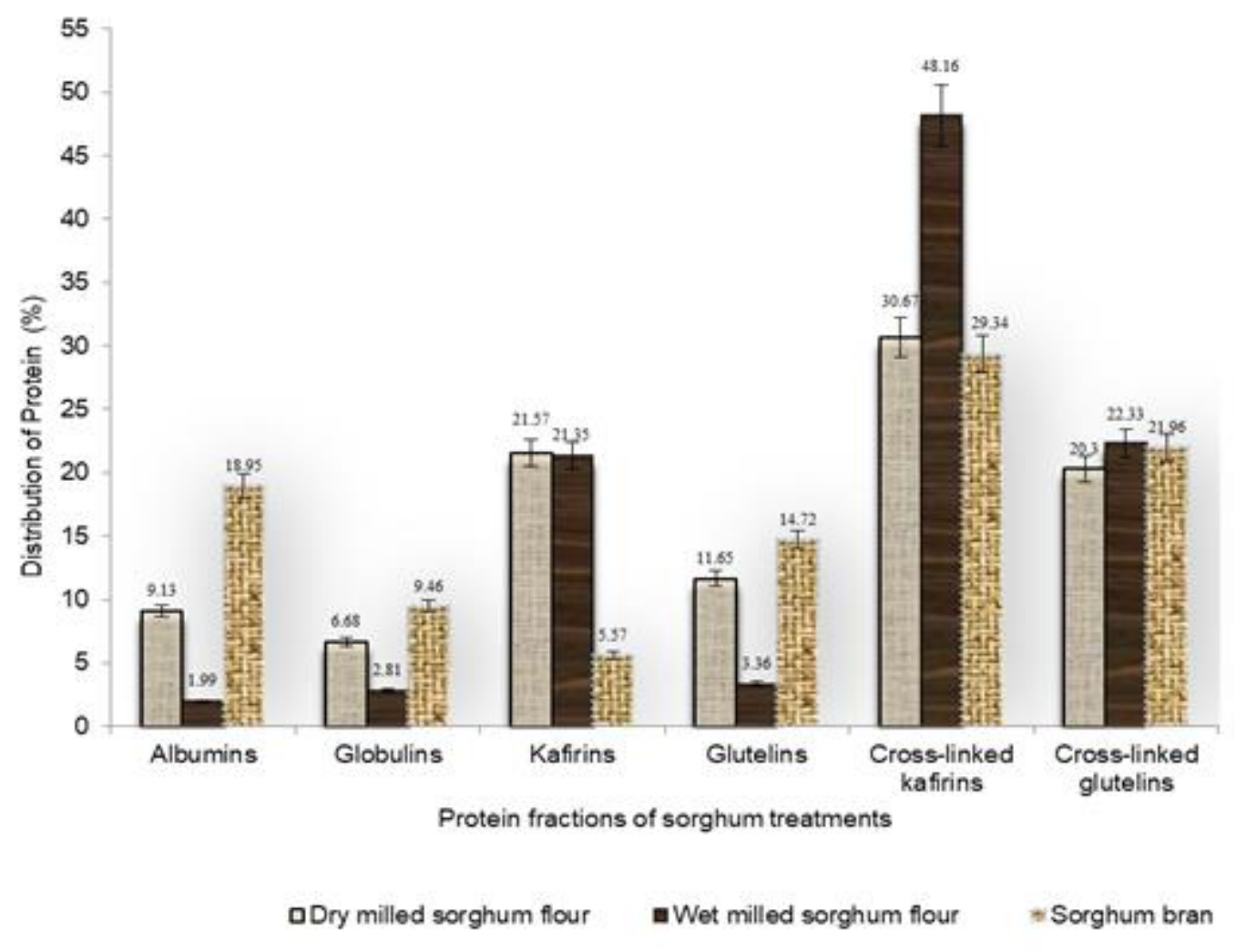

Figure 2 distribution of protein fraction in the bran and dry-milled and wet-milled four of sorghum 
Table 2 Extracted protein fraction $(\mathrm{mg} / \mathrm{mL})$ of sorghum flour and bran

\begin{tabular}{lccc}
\hline \multirow{2}{*}{$\begin{array}{c}\text { Protein fractions } \\
(\mathrm{mg} / \mathrm{mL})\end{array}$} & \multicolumn{2}{c}{ Sorghum Flour } & Sorghum bran \\
\cline { 2 - 3 } & Dry-milled & Wet-milled & \\
\hline Albumin & $95.77 \pm 0.14^{\mathrm{a}}$ & $18.04 \pm 0.06^{\mathrm{b}}$ & 382,59 \\
Globulin & $70.13 \pm 0.11^{\mathrm{a}}$ & $25.43 \pm 0.58^{\mathrm{b}}$ & 191.10 \\
Kafirin & $226.42 \pm 0.39^{\mathrm{a}}$ & $193.62 \pm 1.41^{\mathrm{b}}$ & 112.45 \\
Cross-linked & $321.92 \pm 1.01^{\mathrm{a}}$ & $436.68 \pm 1.20^{\mathrm{b}}$ & 592.46 \\
kafirins & & & \\
Glutelin & $122.27 \pm 0.62^{\mathrm{a}}$ & $30.45 \pm 0.07^{\mathrm{b}}$ & 297.31 \\
Cross-linked & $213.01 \pm 1.09^{\mathrm{a}}$ & $202.50 \pm 0.80^{\mathrm{b}}$ & 443.55 \\
Glutelins & & & \\
\hline
\end{tabular}

Remarks : Values are means \pm SD. Subscript in the same row followed by the same letter are not significantly different at $\mathrm{p}<0.05$.

Globulin fraction is a fraction of protein that is not water soluble but is soluble in salt. Globulin fraction is also called as stored proteins, which is the protein that is stored for metabolic processes. Dry milled sorghum flour has an average concentration of $70.13 \mathrm{mg} / \mathrm{L}$ which was greater than the wet milled sorghum flour $25.76 \mathrm{mg} / \mathrm{L}$. Globulin is one of the easily denatured protein in hot conditions, so that the process of grinding and drying can reduce the content of globulin fraction (Yuwono et al., 2003). Wet milled sorghum flour has a lower globulin fraction $(2.81 \%)$ compared to the one in dry milled sorghum flour $(6.68 \%)$. This is due to the drying factor using the cabinet tray dryer after the grinding process. The results of the research conducted by Afify et al. (2012) showed that protein globulin consisted in sorghum was $11.37 \%$ to $12.67 \%$.

Kafirin fraction is a protein fraction that is soluble in nonpolar solvents such as alcohol. The kafirin fraction is found as a deposit protein in cereal plants. In sorghum, this fraction is the most protein fraction. The kafirin fraction in this study showed that the average protein concentration in dry milled sorghum flour was higher than that of wet milled sorghum flour which was $226.42 \mathrm{mg} / \mathrm{L}$ and $193.62 \mathrm{mg} / \mathrm{L}$, respectively. According to Taylor et al. (1985) the kafirin fraction is found in the part of sorghum endosperm, the loss of some layers of endosperm during the immersion and milling process (Anglemeir and Montgomery, 1976; Suarni and Patong, 2002; Merdiyanti, 2008) can reduce the number of kafirin fraction. Figure 2 shows that the wet method of grinding resulted in a decrease in the protein concentration of the kafirin fraction in sorghum flour. The proportion of kafirin in sorghum protein appeared to be variable, which can be given better methods to quantify the kafirin concentrations (Selle et al., 2010).

Cross-linked kafirin fraction is a cross disulfide bond in the kafirin 
monomer. Wet milled sorghum flour has a higher protein concentration than dry milled sorghum flour. The average concentration of wet and dry milled flour was $436.68 \mathrm{mg} / \mathrm{L}$ and $321.92 \mathrm{mg} / \mathrm{L}$, respectively.

Glutelin fraction or glutelin-like protein fraction is a protein fraction that is insoluble in neutral $\mathrm{pH}$ solvents but is dissolves in acidic or basic solutions. Dry milled sorghum flour has higher protein concentration than the protein concentration in wet milled sorghum flour. Dry milled flour and wet milled flour obtained an average protein concentration of $122.27 \mathrm{mg} / \mathrm{L}$ and 30.45 $\mathrm{mg} / \mathrm{L}$, respectively. The cross-linked glutelin fraction is a crosslinking of glutelin. This fraction indicates that the concentration of glutelin cross-linked protein in dry milled sorghum flour had a higher protein concentration than in wet milled sorghum flour. The average concentration of dry and wet milled flour were $213.01 \mathrm{mg} / \mathrm{L}$ and $202.50 \mathrm{mg} / \mathrm{L}$, respectively. The concentration of glutelin cross-linked was proportional to the glutelin-like protein fraction but the concentration obtained was higher, i.e. $21.31 \%$ to $22.45 \%$ for the cross-linked glutelin fraction, and $8.30 \%$ to $9.35 \%$ for the gluten fraction (Afify et al., 2012). The KD-4 variety of sorghum flour respectively has protein cross-linked glutelin and glutelin fraction of $20.30 \%$ and $11.65 \%$ in dry milled sorghum flour, while in wet milled sorghum flour they were $22.33 \%$ and $3.36 \%$.

The results of albumin fraction, globulin, kafirin, cross-linked kafirin, glutelin, cross-linked glutelin, in bran were $382.59 \mathrm{mg} / \mathrm{L}, 191.10 \mathrm{mg} / \mathrm{L}, 112.45$ $\mathrm{mg} / \mathrm{L}, 592.46 \mathrm{mg} / \mathrm{L}, 297.31 \mathrm{mg} / \mathrm{L}, 443.55$ $\mathrm{mg} / \mathrm{L}$, respectively. The cross-linked fraction of bran kiririn was more than the other fractions. According to Anglemeir and Montgomery (1976), there will be a release of protein bonds during the immersion process, so that the polar residue of protein albumin fraction will dissolve and interact with water. This made the protein concentration of albumin fraction in wet milled sorghum flour quite small, as much as $1.99 \%$, compared to the protein concentration of albumin fraction in dry milled sorghum flour that was as much as $9.13 \%$.

Table 2 shows that the method of wet milling and dry milling has an effect on the protein fraction of sorghum flour. Dry milled sorghum flour has higher protein concentration than wet milled sorghum flour, except the kafirin cross-linked fraction. The result of each protein fraction obtained from these two milling methods were significantly different with a confidence level of $95 \%$. The use of 2ME and SDS solvents affects the protein concentration values of cross-linked fractions. 2-ME solvents and SDS bind to kafirin's cross-linked proteins (Afify et al., 2012).

\section{Protein profile using a SDS-PAGE}

Investigating the profile of the sorghum flour protein fraction by using SDS-PAGE was carried out to determine the protein molecular weight. The results of SDS-PAGE protein fraction of dry milled sorghum flour, wet milled, and bran can be seen in Figure 3. Figure 3 only shows a few fractions that the ribbons were clearly visible. The ribbons in cross-linked kafirin fraction for dry sorghum flour were clearly seen with molecular weights of $16.95 \mathrm{KDa}, 13.13$ $\mathrm{KDa}$, and 9.54 KDa. Wet milled sorghum flour showed ribbons in the cross-linked fraction of the kafirin with a molecular weight of $19.49 \mathrm{KDa}$. On the other hand, the protein ribbon on sorghum bran did not appear clearly.

The results of electrophoretic patterns of dry milled sorghum flour, wet milled sorghum flour, and sorghum bran were 
shown in Figure 3. Figure 3 only shows a few fractions that the ribbons were clearly visible. The ribbons in cross-linked kafirin fraction for dry sorghum flour were clearly seen with molecular weights of $16.95 \mathrm{KDa}, 13.13 \mathrm{KDa}$, and $9.54 \mathrm{KDa}$. According to Hamaker et al. (1995), the kafirin cross-linked fraction is between 14.4 KDa to $45 \mathrm{KDa}$. This shows that the cross-linked fraction of the dry milled sorghum flour has a $\beta$ protein with a molecular weight of 16.95 , while the molecular weights of $13.13 \mathrm{KDa}$ and 9.54
KDa show a non-kafirin fraction. Wet milled sorghum flour showed a ribbon in the cross-linked fraction of the kafirin with a molecular weight of $19.49 \mathrm{KDa}$. In dry milled sorghum flour, more protein bands appeared than in wet milled sorghum flour. This indicates that there was an effect of milling process on protein fractions. Bran protein band was not seen, even though according to Hamaker et al. (1995), the kafirin cross-linked fraction was often found in sorghum endosperm. (a)

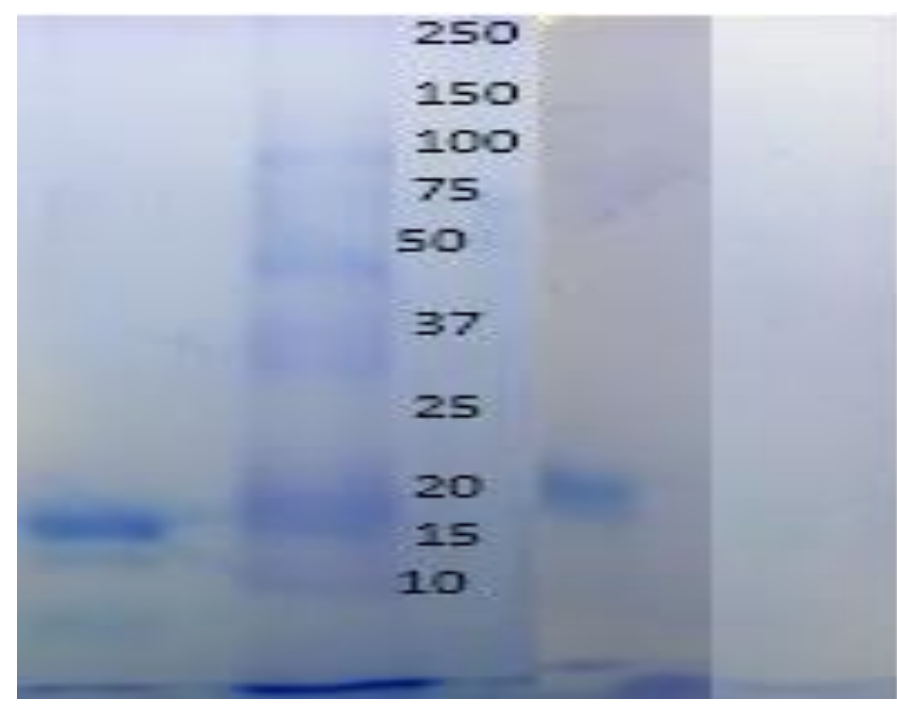

Figure 3 SDS-PAGE of cross-linked kafirins fractions; (a) dry-milled sorghum flour; (b) Molecular weight protein markers; (c) wet-milled sorghum flour; and (d) sorghum bran

\section{CONCLUSION}

The method of wet and dry millings has an effect on the protein fraction of sorghum flour. Dry milled sorghum flour had higher protein concentration than wet milled sorghum flour, except the kafirin cross-linked fraction. The result of each protein fraction obtained from these two milling methods were significantly different with a confidence level of $95 \%$. The analysis to determine the protein profiles by using SDS-PAGE showed differences in both milling methods, dry milled sorghum flour had more protein ribbons of kafirin cross-linked fraction, whereas wet milled sorghum flour only had a small number of protein fraction ribbons from the cross-linked kafirin.

\section{ACKNOWLEDGEMENT}

We would like to thank the Indonesian Agency for Agricultural Postharvest Research and Development (ICAPRD)-Ministry of Agriculture, Republic of Indonesia, for financial and technical support. The research is 
collaboration activity with Gluten Free Indonesia, PT. and DIPA-ICAPRD.

\section{REFERENCES}

Afify, A. E. M. R., El-Beltagi, H.S., ElSalam, S.M.A, Omran, A.A.. (2012) 'Protein Solubility , Digestibility and Fractionation after Germination of Sorghum Varieties', PLoS ONE, 7(2), pp. 1-6. doi: 10.1371/journal.pone.0031154.

Anglemeir, A. E. and Montgomery, M. W. (1976) Amino acids peptides and protein. New York: Marcel Decker Inc.

Awadalkareem, A. M., Mustafa, A. I. and Tinay, A. H. El (2008) 'Protein , Mineral Content and Amino Acid Profile of Sorghum Flour as Influenced by Soybean Protein Concentrate Supplementation', Pakistan Journal of Nutrition, 7(3), pp. 475-479.

Baxter, G., Blanchard, C. and Zhao, J. (2004) 'Effects of Prolamin on Rice (Oryza sativa L.) Textural and Pasting Properties', J Cereal Scie, 40, pp. 1-29.

Chiang, P.-Y. and Yeh, A.-I. (2002) 'Effect of Soaking on Wet-milling of Rice', Journal of Cereal Science, 35(1), pp. 85-94. doi: 10.1006/jcrs.2001.0419.

Duodu, K. G., Taylor, J.R.N., Belton, P.S., and Hamaker, B.R. (2003) 'Factors affecting sorghum protein digestibility', Journal of Cereal Science, 38, pp. 117-131. doi: 10.1016/S0733-5210(03)00016-X.

Hamaker, B.R., Mohamed, A.A., Habben, J.E., Huang, P.E., Larkins, B.A. (1995) 'Efficient procedure for extracting maize and sorghum kernel proteians reveals higher prolamin contents than the conventional method', Journal Cereal Chem., 72(6), pp. 583-588.

Hulse, J. . and Pearson, O. (1980) Sorghum and the millest, their composition and nutritive value. New York: Academic Press.

Lowry, O. H., Rosebrough, N.J., Farr, A.L., Randall, R.J. (1951) 'Protein Measurement With The Folin Phenol Reagent', J. Biol. Chem., 193, pp. 265-275.

Mcdonough, C. M., Floydb, C.D., Waniskaa, R.D., Rooney, L.W. (2004) 'Effect of accelerated aging on maize, sorghum, and sorghum meal', Journal of Cereal Science, 39, pp. 351-361. doi: 10.1016/j.jcs.2004.01.001.

Merdiyanti, A. (2008). Paket Teknologi Pembuatan Mi Kering Dengan Memanfaatkan Bahan Baku Tepung Jagung. Departemen Teknologi Ilmu Pangan. Institut Pertanian Bogor.

Mesa-Stonestreet, N., Alavi, S. and Bean, S. (2010) 'Sorghum proteins: the concentration, isolation, modification, and food applications of kafirins', J. Food Scie., 75(5), pp. 90-104. doi: 10.1111/j.17503841.2010.01623.x.

El Nasri, N. A. and Tinay, A. H. El (2007) 'Functional properties of fenugreek (Trigonella foenum graecum) protein concentrate', Food Chemistry, 103, pp. 582-589. doi: 10.1016/j.foodchem.2006.09.003.

Pedroche, J., Yust, M.M., Lqari, H., Megi'as, C., Giro, J., Alaiz, M., Milla, N.F., Vioque, J. (2005) 'Chickpea pa2 albumin binds hemin', 168(Plant Science), pp. 1109-1114. doi: 10.1016/j.plantsci.2004.12.011.

Pinciroli, M., Vidal, A.A., Anon, M.C., Martinez, E.N. (2009) 'Comparison between protein functional properties of two rice cultivars', Food Science and Technology, 42, pp. 1605-1610. doi: 10.1016/j.lwt.2009.06.003. 
Ragab, D. M., Babiker, E. E. and Eltinay, A. H. (2004) 'Fractionation, solubility and functional properties of cowpea (Vigna unguiculata) proteins as affected by $\mathrm{pH}$ and / or salt concentration', Food Chemistry, 84, pp. 207-212. doi: 10.1016/S0308-8146(03)00203-6.

Schons, P. F., Battestin, V. and Macedo, G. A. (2012) 'Fermentation and enzyme treatments for sorghum', Brazilian Journal of Microbiology, (June), pp. 89-97. doi: $10.1590 / \mathrm{S} 1517$ 838220120001000010.

Selle, P. H., Cadogan, D.J., Li, X., Bryden, W.L. (2010) 'Implications of sorghum in broiler chicken nutrition', Animal Feed Science and Technology. Elsevier B.V., 156, pp. 57-74. doi: 10.1016/j.anifeedsci.2010.01.004.

Suarni and Patong, R. (2002) 'Komposisi Kimia Tepung Beberapa Varietas/Galur Sorgum sebagai Bahan Substitusi Terigu', Penelitian Pertanian Tanaman Pangan, 21(1), pp. 43-48.

Suksomboon, A. and Naivikul, O. (2006) 'Effect of Dry- and Wet-Milling Processes on Chemical, Physicochemical Properties and Starch Molecular Structures of Rice Starches', Kasetsart J. (Nat. Sci.), 40, pp. 125-134.

Susanto, E. (2010) 'Penggunaan SDSPAGE untuk karakterisasi fraksi protein sebagai alternatif metode identifikasi pencampuran daging babi ke dalam bakso', Jurnal Pertanian, 1(1), pp. 1-7.

Taylor, J. R. N., Schussler, L. and Liebenberg, N. W. (1985) 'Protein body formation in the starchy endosperm of developing Sorghum bicolor (L.) Moench seeds', S. Afr. J. Bot., 51(1), pp. 35-40. doi: 10.1016/S0254-6299(16)31699-4.
Widowati, S. and Damardjati, D. S. (2001) 'Menggali Sumberdaya Pangan Lokal dan Peran Teknologi Pangan Dalam Rangka Ketahanan Pangan Nasional', Majalah Pangan BULOG, 36(10), pp. 3-11.

Yoenyong-buddhagal, S. and Noomhorm, A. (2002) 'Effect of Raw Material Preparation on Rice Vermicelli Quality', Starch/Stärke, 54, pp. 534-539.

Yuwono, S. S., Hayati, K. K. and Wulan, S. N. (2003) 'Karakterisasi Fisik, Kimia dan Fraksi Protein 7S dan $11 S$ Sepuluh Varietas Kedelai Produksi Indonesia', Jurnal Teknologi Pertanian, 4(2). 